\title{
Adversative Discourse Markers in Kurdish Literary Texts
}

\author{
Paiman Hama Salih Sabir ${ }^{1} \&$ Hoshang Farooq Jawad ${ }^{1}$ \\ ${ }^{1}$ English Department, College of Basic Education, University of Sulaimani, Iraq \\ Correspondence: Paiman Hama Salih Sabir, English Department, College of Basic Education, University of \\ Sulaimani, Iraq.
}

Received: November 13, 2018

Accepted: December 12, 2018 Online Published: December 15, 2018

doi: $10.5539 /$ elt.v12n1p154

URL: https://doi.org/10.5539/elt.v12n1p154

\begin{abstract}
Discourse Markers are one of an uninvestigated aspect of language in old and modern Kurdish linguistics, that has not been given due attention, neither by native nor non-native researchers. On this ground, it is hoped that the present study sheds light on this almost entirely ignored aspect of the language and this study is meant to be a systematic treatment of this group of lexical items known as Discourse Markers (henceforth, DMs), more specifically one category of them; Adversative DMs.

DMs are words, phrases and even clauses that enhance discourse coherence and are found in all languages, as tapped on by researches and investigations. Numerous terminologies are utilized to refer to such group of markers by different researchers in English and other languages, such as 'Discourse Particles, Cue Phrases, Small Words, Pragmatic Markers, Discourse Connectives... and even they are defined differently.

It is postulated that DMs are meaningless and lay outside the domain of sentence structure. Likewise, lexical expressions that have different grammatical functions such as 'and, also, but, or, simultaneously, at the same moment ...etc, can also function as DMs to connect the previous utterance with the upcoming discourse segment.

The current investigation endeavors to answer certain specific questions: first, the extents to which DMs are operated in literary texts; second, discourse functions DMs implement. Thirdly, the word categories DMs are derived from, and to which extent Halliday and Hassan (1976)'s framework is applicable to Kurdish DMs?

For achieving the aims, the researchers analyzed one of the contemporary novels of a famous novelist entitled 'Xezlenûs w Bâxekâni Xejâł'. By applying Halliday and Hasan's (1976) framework and also by taking insights from Fraser (2009), DMs are categorized into different classes. One of which is Adversative DMs, which are the concern of the present study.

For obtaining the frequency of each marker, the data are scrutinized manually, since there are no corpus analysis tools that can facilitate such measurements.

The study concludes that Adversative DMs are frequently used in selected Kurdish literary texts and that they are similar to those found in English in terms of derived grammatical categories, taxonomy, and they have different characteristics in terms of form, position and discourse functions. Withal, it has been arrived that Adversative DMs are of different kinds analogous to those investigated in English by Halliday and Hassan (1976).
\end{abstract}

Keywords: discourse markers, adversative DMs, adversative DMs in Kurdish, classification of adversative DMs, application of Halliday and Hasan's (1976) model

\section{Introduction}

One of the vital constituents of the spoken and written discourse is a certain group of words and phrases such as 'but, whereas, rather, in fact, however, yet, on the contrary, etc.' that serve to have grammatical functions, despite their discourse utilities. They are considered the salt and flavor of utterance. Such lexical items are labeled differently since they are up-to-date subject under investigation and each researcher studies them from a different perspective. They are studied in English, French, Germanic, Arabic, Persian, Finnish and some other languages under different terms and in different contexts whether spoken or written, but in Kurdish they are left almost untouched. Hence, the researchers endeavor to study these markers within the written context, namely within one of the contemporary novels. 


\subsection{Discourse Markers}

DMs are of important in both semantic and pragmatic aspects of language as recent investigations expose. Blakemore (2002), for instance, in the introduction of his book outlines the significance of these markers, reporting that; "They are regarded as central to semantics because they raise problems for standard theories of meaning, and to pragmatics because they seem to play a role in the way discourse is understood". However, defining the term DMs is not as straightforward, since it is one of the recent fields under investigations presently that researchers and scholars study them from distinctive perspectives and approaches. Thus, there is not a single term for such a group of lexical elements that function on discourse level, even the definitions are not unified, and each researcher defines them from a different standpoint. Not only that, but also deciding on what lexical element (s) is a DM and what is not a DM is dissimilar and each scholar studies a group of lexical elements and considers them as these markers.

In the $1970^{\mathrm{s}}$ linguists described DMs as mysterious elements in language, for instance Langocre $(1976 ; 468)$ refers to DMs, as a group of 'mystery particles', which were in free variation; according to him the word-class, distribution and meaning, of DMs are opaque. Therefore, they are described as "simply salt-and-peppered through a text to give it flavor". Schiffrin (1987: 31) whose work is considered one of the comprehensive works on DMs and embraces a coherence approach to the study of these markers defines them as 'sequentially dependent elements, which bracket units of talk'. On the other hand, Fraser (1999) and Andersen (2001: 39) pursue a pragmatic approach and recognize DMs as a class of short, recurrent linguistic items that generally have little lexical import but serve significant pragmatic functions in conversation. On behalf of Blakemore (2002: 151) who adopts a structural approach, states that "discourse, like a sentence, exhibits hierarchical structure" and that "discourse markers or connectives are defined in terms of the role they play in 'marking' these structural relations between segments, and the key to their analysis lies in the classification of the kinds of relations that exist between text segments". From the functional perspective, Castro (2009: 59) and Ford and Thompson (1996) describe them as a set of elements, which help participants negotiate the boundaries of conversational actions. Whereas Mosegaard Hansen (1998: 73) defines them as "non- propositional linguistic items whose primary function is connective, and whose scope is variable",

From what has been reviewed above, it can concluded that DMs are certain linguistic elements formally diverse, i.e., from different parts of speech but functionally analogous that beckon text coherence, and attain text relevance through which different pragmatic functions of the text or discourse can be achieved, such as managing and initiating the discourse

\subsection{Classifications of Adversative DMs in Kurdish}

In order to isolate the DMs of adversative in the novel, the researchers depend on Halliday and Hasan (1976) framework. Since the classification does not cover conditions or certain criteria to recognize DMs; henceforward, Frasers' (2009) model is utilized for that purpose. Fraser proposes that (2009: 297) DMs must meet three requirements:

1) A DM is a lexical expression, for example, but, so, and in addition.

2) In a sequence of discourse segments S1-S2, a DM must occur as a part of the second discourse segment, S2.

3) A DM does not contribute to the semantic meaning of the segment but signals a specific semantic relationship, which holds between the interpretations of the two Illocutionary Act segments, S1 and S2.

However, sorting out Kurdish DMs depending on the proposed model is not an easy task. Since there are certain DMs that can be classified under two sub-categories, for instance 'heštâ' (however) is categorized as ' $a$ ' and 'b' sub-types of Adversative DMs. Correspondingly and depending on the two models, the following sub-categories are identified as adversative DMs in Kurdish.

a. Adversative relations 'proper' ('in spite of external and internal)

Simple: héštâ (yet), eger čîl ger čĭ (though), tenhâ (only).

b. Contrastive relations ('as against') (external):

Simple: belâm, welé, bełkû (but),

c. Contrastive relations ('as against') (internal):

Avowa: le râstîdâ (in fact)/ (as matter of fact),( râstjekei) to tell the truth, be râstî (actually), in point of fact.

d. Corrective relations ('not... but') (internal):

Correction of meaning: kečî (instead), betkû (rather), be péčewânewe (on the contrary). 
Correction of wording: at least, rather, I mean.

e. Dismissive (generalized adversative) relations ('no matter...still') (external internal):

Dismissal, closed: in any case, in either case, whichever.

Dismissal, open-ended: (anyhow, at any rate, in any case.

\subsection{Adversative DMs}

Adversative denotes contrary to the fact. Adversative DMs are the second group of markers within the taxonomy of Halliday and Hasan (1976). This kind of relation can be conveyed by a number of markers categorized by Halliday and Hasan (1976) as: simple, complex, emphatic, contrastive, etc., and meaning, cohesion can be found on both planes of talk, external and internal (i.e.,) the expectation may be derived from the content of what is being said, or from the communication process, the speaker-hearer situation.

Fraser (2009) labels most of the adversative DMs as 'contrastive'. He (ibid) relies upon Hallidayan (1976) framework in his classifications; though, his taxonomy includes a smaller number of DMs and he (ibid) does not discriminate between internal and external meanings.

Adversative DMs, which are chosen from the Kurdish novel then investigated and analyzed turn out to be from different parts of speech, such as correlative conjunctions (bałâm), prepositional phrases (le hemân kâtdâ), adverbials (hetâ) and even from grade particles such as 'héštâ', and prepositions 'le péš', complex preposition.

In pinpointing the markers, difficulties arose in identifying the appropriate translation and even the function of each marker, since no proper study is conducted in this concern, for instance 'héštâ' is translated as both 'yet' and 'still', but no studies differentiate between them, while in English numerous studies are accomplished in this area. Meanwhile, 'but' is studied on the syntactic level, whereas its real meaning within the context is left untreated, which can be diverse as those found in English. Even in detecting the parts of speech of the markers difficulties ascend, as there is no such a dictionary that embraces all the lexical items of the language. Therefore, the researchers draw insights from the small number of studies (if found) on the lexical items, and take insights from findings on these markers on English DMs and apply them to Kurdish DMs (if applicable).

\subsection{Adversative Proper}

In spite of is the meaning that is implied by this group of markers, as reported by Halliday and Hasan (1976), Adversative meaning can be expressed internally or externally. In its simplest form, adversative proper in Kurdish can be articulated as follows:

\subsubsection{Simple Adversative}

\section{hešta, eger čî (ger čî), tenhâ \\ Heštâ (yet)}

Kurdish grammarians have not given an authentic account to this linguistic expression. McCarus (1958: 79) proffer only little information about 'héštâ'. He (ibid, 1958: 79) estimates it within 'time adverb', and glossed as 'yet' and 'still'. However, further account is not reported in this concern. In The Sharazoor (2000: 594) Kurdish-English dictionary, it is pinpointed as an adverb and exemplified to mean 'yet' and 'still' as follows:

1) heštâ nweja.

It is still new.

2) heštâ le nebuitetewe.

You haven't finished yet. (The Sharazoor Dictionary, 2000: 594)

On the other hand, In English, study results on this topicreport different outcomes concerning this marker, for instance Ranger (2015: 163) in his study on yet and since, characterizes 'yet' as locating an occurrence on the offline position (IE) on a notional domain of discourse with a preconstructed position (I or E) on the same domain, whereas 'still' locates an occurrence at notional domain, contains with a preconstructed position on the same domain" (Ranger, 2015: 163). Ranger's investigation is done through TEPO theory; however, in the current study, details are not provided of the theory.

Ranger (2015: 163) concludes that 'yet' and 'still' have three DM values; concessive 'yet, concessive 'still', and conclusive 'still', but what seems vague is that he does not refer to the contrastive meaning of these markers.

Fraser (2009) and Fraser (2010) classify 'yet' as a 'contrastive DM, by "contrastive" he means the relationship between "the S2 they introduce and a foregoing S1, although in some cases they signal more than simple 
contrast", (Fraser, 1998: 301), whereas in the Hallidayan (1976) framework, 'yet' is one of the simple adversative relation, as he affirms that " An external Adversative relation is expressed in its simple form by the word 'yet' occurring initially in the sentence", (Halliday \& Hasan, 1976: 250). So, the condition for English 'yet' to be considered as an Adversative device is Initiality within the sentence.

In the novel 'Xazalnus w Baghakani Xayâll', 'heštâ' occurres in different contexts, the following excerpts clarify certain uses;

3) legeł ewei dunjâ mał ewâî le dwâhamîn gełâ weriwekâni xezân dekrid, heštâ hendê goličkei wird leser gorekei mâbûn. (Ali, 2014: 736).

4) Trîfe Jâ behrî le midâłyewe bunewareki xejâłâwi bû, heštâ minâł bû ke serî be ser bermîlî hemâmakedâ šor dekirdewe w seiri ew bunewere xejâłâwjânei dekird ...(Ali, 2004: 214).

In the above selections, 'heštâ' functions as an adverb describing the verb 'bûn' (verb BE) in both sentences, which is correspondent to English 'still'. Considering the occurrences of 'hêštâ' in the following extract;

5) heštâ pei nexistbûa nâw dergâi žûrekei , xânmî Afsâna le dwâwe be čipejeki afsûnâwi gûtî (Ali, 2014: 217).

'Hést $\hat{a}$ ' in such a context functions as an aspectual adverb, and it is glossed as 'yet. It can be called aspectual $h e ́ s ̌ t a ̂$, as an equivalent term for English aspectual 'yet'. But in the following excerpt;

6) dwâ jâr pâšâkân legeł jekdâ dwžmniš bin, heštâ berâber be šâ3irân her brân. (Ali, 2014: 812).

In (6), it can be deduced that heštâ is a DM in terms of position, meaning and discourse function and entails the 'opposite' meaning that can be a counterpart to 'bałâm, (but).

Applying Ranger's (2015) conclusions to 'heštâ', the first two extracts can be considered as 'concessive' DM functioning on 'argument' level (as Ranger, 2015 refers to it), whereas the excerpt (5) can be regarded as aspectual one. And in the last example (6) 'héštâ' is an Adversative DM, as stated in Halliday and Hassan (1976).

Being so, the frequency of 'héštâ' as an Adversative DM in the novel is only once, which is, (\%0. 1) of the whole of the Adversative DMs, though the researchers single out a large tokens in the novel as DM first, depending on their positions within the segments, but when applied Ranger (2015) meaning, and from insights of Halliday and Hasan (1976), it has been resolved that only one instance is Adversative DM, and the pattern is as follows:

\section{S1, DM S2.}

Hence, it is observed that 'heštâ' does not befall initially in the sentence as the condition, which is constrained for English 'yet' to be a DM.

\section{Eger čî / ger čî (though)}

Eger $\check{c} \hat{\imath}$ and ger $\breve{c} \hat{\imath}$ are two other elements that bear Adversative meaning in Kurdish and generally glossed as although and though. Ger $\breve{c} \hat{\imath}$ is the phonologically reduced form of eger $\breve{c} \hat{l}$, similar to although. In English (al) though is considered as a DM if it "occurs after the full stop in writing", (Halliday \& Hasan, 1976: 250).

On the syntactic level, Shwani (2003) provides certain information about eger $\check{c} \grave{\imath}$ and situates it within the list of subordinate particles. In terms of form, it is not counted within the group of simple particles, which has an independent structure and conveys a specific meaning; and in terms of position, (like any other relative particle), it occurs initially within the main clause in complex sentence structure. The main clause usually occupies the first position within complex sentences, though sometimes it exchanges its position with the subordinate clause, but this does not affect the entire meaning of the sentence.

In order to identify the status of (e) ger $\breve{c} \hat{\imath}$ as a DM in the Kurdish novel, the researchers identified (63) tokens while they are part of the second segment, and befall after comma or full stop. Applying the conditions of Fraser (2009) to DMs, the following excerpts are identified to be attested:

7) ke be regâdâ rûew ew šâxe 3âsî serkeše serdekewt, diłnjâ bû, ger či žjânî pre le kirdârî bed feł w nâmerdâne, belâm xoi keseki dił req w roheki reš w reftâr nje (Ali, 2014: 8).

8) ger čl xoi w gazalakâni žjâni emajân pir krdbû le himet, belâm xoi sârdâw kem terxem danwând (Ali, 2014: 24).

9) eger čî min zor hewł dedem wek âmêreki beé rehm îš bikem, ew lâperâna rek bixam ke le berdestmân, ew qisâne polân bikem ke zor câr nârék w pertawâze le lâpere w kâset w čiroki zârakjawa warm girtûn (Ali, 2014: 39). 
10) eger čî nâmakâni ew kurem hemû sûtân, eger či dwâ câr pem gût namawet îtir bit bînm, eger čî hič âfratek nje le dunjâdâ bew kûre błe nâmwe bit bînm. Belâm šitekân zor tirsnâk dačna peše (Ali, 2014: 122).

11) gerčî min Xezal nûsim le nâw bâxa xajâłjakândâ nâsî, bełâm leber hojakî nâdjâr hastim dakird min hargîz roh labarekî xajâłî nîm (Ali, 2014: 283).

12) eger čî min bâgi xajâłim nje wek cenâbtân defermûn, bełâm cenâbi Bârûn ...bałe! wistim błem wâ błem. (Ali, 2014: 44).

From the above data, (e) ger $\breve{c} \hat{\imath}$ is followed by betâm in (7 and 8). Salih (2014: 128) reports that: when ger čî initiates the first segment, the S2 usually starts with 'bełâm'. However, only two instances of 'ger čî' initiates a segment followed by 'bełâm' from the (63) instances analyzed. According to Shwani (2002: 111) the structure of (e) ger $\breve{c} \hat{\imath}$ as a subordinate conjunction would be as follows:

eger čî (opposite) +nominal clause+ V. + opposite particle+ (bałâm) +main clause.

Probing all the (63) samples according to this formula, only one of the occurrences of 'eger čî' can be considered as a DM, which is the extract NO (9), thus the percentage would be $(\% 0.2)$. Therefore, all the remaining (62) instances are considered as coordinators and function on the syntactic level, rather than on the discourse level.

\section{Tenhâ, tenjâ (only)}

The third linguistic element within Adversative proper is tenhâ, which is translated as 'only' in English. It occurs in different positions within the novel, however again only those instances are identified which are considered to be DMs by applying (Fraser 2009) 's conditions. The novelist does not only implement tenhâ but also the Arabic equivalent expression 'bes', as his peculiar style of writing. The Arabic term is used (6) times and each time it is followed by Xwâ, which means 'Alla only', or 'only Alla', for instance:

13) čunke feqet roh leberêk lem hikâjata hâlî debét ke le 3ešiq bfâmét, bes xwâš dezânet ...âxo estâ to le 3ašiq te deeait jân nâ? Bes xwâ dazânet..xwâ (Ali, 2014: 90)

On the grammatical status of 'tenhâ', Mahwi (2011: 244-246) offers some explanations and tags it as 'focus or grade particle'. These particles are free in terms of their positions to some extent on the sentence level and every occasion they convey a new semantic domain, for instance:

14) tenhâ Ârâm dwéné čû bo šânogerjeke. (Only Aram went).

15) Ârâm tenhâ dwéné čû bo šânogerjeke. (Only yesterday, but not another day), (Mahwi, 2011: 246).

Besides, Fattah (1997: 199) classifies it as specifier (Note 1) / distributive, it is like 'her' (just), which is located before the noun head. Considering the following data:

16) le cile ûtû krâwekeidâ , le péšdem qutâbxânekeidâ westâm w čâwarém kird, tenjâ čend deqéqejak ber le dest pé kirdní dewâm, be nâz w 3išwei mâmostâjeki cwânewe geište qutâbxâne. (Ali, 2014: 208).

17) ew tope spjei be dâr nûkaka dei âwažûn, tenjâ séberi komałek dike bet ke eme nâjân binîn. (Ali, 2014: 18).

Accordingly and as reported by Fattah (ibid: 199) all the instances which are like the above in meaning, position and even semantic effect can be considered as a specifier, not a DM.

If observing the following occurrences from the novel;

18) to zor le meža êrat nabiîniwa, wâ nje? Zor demeka? Zuhdî be mândû bûneki zorewe gûtî " bes tenhâ xwâ dezânet čend sâła min rištûm (Ali, 2014: 319).

In the above discourse segment, bes functions as a DM whereas tenja is a specifier, which specifies the meaning of the following word Xîâ. Even depending on Fattah (1997) the sequencing order of specifiers, bes can be considered as a DM, as he organizes the sequence of specifiers as follows;

Distributive + demonstrative + qualifier + head

Among the specifiers, he demonstrates her (just) and tenhâ (only); nevertheless, he (ibid) does not report on the occurrence of two specifiers in cluster or sequence.

\section{B. Contrastive Relation}

\section{Belâm, welē, belkû (but)}

Betâm is the stereotyped linguistic element to express different meanings in utterance, among which is 'contrast'. Literature on Kurdish grammar comprises certain treatments of 'bełâm' as one of the commonly used words in both spoken and written forms. Ibrahim (1986: 25) indexes betâm as a simple syntactic particle that junctions two sentences. Betâm is designated as one of the relative particles that glues or combines two simple 
independent sentences, but does not belong to either of them. Semantically, it balances simple sentences, Shwani (2002: 88). As for Mahwi (2011: 238) betâm is a non-inflectable coordinate conjunction that links identical sentences or parts of sentences, as in;

19) Ârâm péwista kâr bikât bełâm tâqeti nje.

Whereas McCarus (1958: 186) marks betâm as a member of conjunctional class, just like 'we' (and). Correspondingly, in generative grammar, betâm' is treated as a coordinate conjunction that functions as " linker between words, phrases or clauses" and that the clauses they link are 'sequentially fixed', Fattah 91997: 186). Betâm is like 'w' and 'yân' restricted to initial position in the clause and does not permit to be preceded by another coordinate conjunction, as:

*žin bełâm pjâw.

Nonetheless, in Kurdish literature a comprehensive account on its semantic and pragmatic aspects cannot be found. On the discourse level, Salih (2014) considers it as 'connective marker; though, he (2014) takes insights from Halliday and Hasan (1976), but he considers such a treatment of Adversative relation as ambiguous if applied to Kurdish; therefore, he recommends another 'less ambiguous' treatment of 'bełâm' depending on Blakemore (1987) procedural meaning.

In English, a number of researchers such as Blakemore (1987) and Blakemore (2002), Schifirin (1987), Fraser (2009) and Fraser (1998) and Halliday and Hasan (1976) reviewed the function of 'but' from its different perspectives. Halliday and Hasan (1976: 250) identify two types of 'but'; 'but' which contains 'and', and the other is 'contrastive 'but', which is applied to Kurdish 'but' in this study.

It is worth notice that in Kurdish betâm is a complicated linguistic element with different implications, and sometimes in one context, it can have two interpretations. In terms of frequency, betâm is another DM which is most widely used, though according to Hallidayan (1976) framework it has two types in terms its category as a DM, yet its use and meaning bear more than two types; therefore, insights from Fraser (2009) would be adapted, since it is more elaborative, especially for identifying the contrastive meaning of but. Halliday and Hasan (1976) have a detail discussion on its contrast meaning without providing detailed treatment, but Fraser (2009) offers a comprehensive and detailed exposition that differentiates between direct and indirect (implied) contrast.

It is reveled that most of the instances of betâm from the novel are predominantly implied contrast that may be due to the nature of the novel, which is an imaginative one. But the taxonomy of Halliday and Hasan (1976) would be applied as the basic framework. As for Blakemore (1987) isolates four uses of 'but' which are 'denial of expectation', 'contrast', 'correction' and 'cancellation'.

Fraser (1998) and Fraser (2009) have a detailed treatment of 'but'. For Fraser (1998) and (2009) and all his works on DMs, he (ibid) categorizes 'but' as Contrastive. For every use of 'but' there is a relevant contrast between the segments of the S1-but-S2 sequence, Fraser (2009: 308). For him (ibid) the segments contrasted are not always identical, sometimes the contrast is direct, (i.e.,) the segments being contrasted have one semantically contrasted sets $(\mathrm{SC} \mathrm{Sc})$ and sometimes two and the segments contrasted are either declarative, imperative or parallel in structure. On the other hand, in indirect contrast both the segments contrasted or involved include an implied comparison, such as;

20) A. My father is a professor. B. But your father is NOT a professor (Direct).

21) A. The king is dead. B. But there is no king. (Indirect) (Fraser, 2009).

On the discourse level, there are uses of 'but' which do not function as DM, but reflect pragmatic function such as that for 'topic change' as in;

22) A. It is unbelievable. B. But John got married. (Fraser, 2009).

What is more, 'but' can also be used in contexts followed by 'of course', which Fraser (2009) treats as certain cases, but without exposing any clarification for them; therefore he (2009) only states 'I have no adequate analysis'. Such as'

23) It is done. B. But of course it' done (Fraser, 2009).

In such a case as the above one, 'but' may or may not function as a DM.

As its reflected in the frequency of uses, the contrast use is more than of 'but' containing 'and'.

As follows, a number of instances would be chosen from the novel and the type of 'belâm' would be decided upon with an interpretation; 
In the novel, betâm is sometimes is used in a meaning that contains 'and',

24) detewêt hendê nâbînâ legał xot berït bo sefereke? Min gûtm bełê, bełâm seférakei min seferêkiî xejâłje (Ali, 2014: 26).

In the above extract, batâm is not used in a sense that the speaker wants to add a contrastive information to the interlocutor, rather the speaker agrees to take some blind people with him to the journey, but he adds information to the type of the journey, which is not like any journey (this is expressed by but, bełâm) and it is also an imaginative one, too.

According to Schifirin (1987: 164), interpretation of such an example is that "the speaker tries to return to prior concern-to return to the fulfillment of a prior expectation imposed upon them by the question".

25) diłî xoi bewe xoš kirdwe ke endâmeki berzî hizbe, betâm bewe râ nedehât kičekei nabéte hîč (Ali, 2014: 58).

In the above excerpt, the novelist reports on one of his characters, Said Bajo. Ali (2014:58) negotiates the state of the mind of this father that he is happy to be a known figure in the party, but (and) this is not the whole pleasure, since his daughter cannot achieve what his family wishes, since she is not successful in her study.

26) tâke šték be zârimdâ hât ewe bû błém lé gerén âsûde bixawét, bełâm râsjeki xošim nem dezânî mebestim čje. (Ali, 2014: 31).

27) râst daikait bâzâr xejâł dekužet , heq be toje, âh bełâm žjân le bâzâreki čapał w pir xoł w xašâk bew lâwe hîči tir nja (Ali, 2014: 216).

28) dengeki qûł bû. tirsnâk bû, bałâm pir bû la xajâł (Ali, 2014: 141).

29) sjânjân żin bûn śûjân kirdbû, betâm hersekjân bed bext u čâre reš bûn (Ali, 2014: 176).

The last example can be decoded in two ways; first, to show two aspects of those three women who were married but their marriage does not bring them happiness (as an additional meaning). Or as contrast, that despite of being married; they were not happy.

The frequency of bełâm that contains ' $w$ ' is (300) times, other examples of this sort of meaning of batâm can be found in pages $(61,65,88,95,97,133,137,146,148,153,161,171,179,137,186,195,196,197,199,198$, 199, 200, 206, 216, 217, 222, 230, 254, 262, 270, 392, 357, 389, 448, 459, 469, 511,515, 530, etc...)

The second sort of meaning conveyed by betâm is contrast. As indicated, the contrast mentioned by Halliday and Hassan (1976: 252) is that contrast means 'against that'. For Schifirin (1987: 176) contrast is part of the meaning of every use of 'but' it "marks an upcoming unit as a contrast with a prior unit".

However, Halliday and Hasan (1976) do not provide details whether the contrast is forward, direct or implied, which is clarified by Fraser (1998: 336). He (ibid) describes that contrast meaning is expressed by lexes such as 'but' as "These discourse markers signal that the speaker intends the explicit message conveyed by $\mathrm{S} 2$ to contrast with an explicit or indirect message conveyed by S1". Furthermore, in such a sense however can alternate 'but', but not vice versa. Thus, the meaning of contrast is explicit, which can be noticed in the following examples from the novel;

30) to her błe dro dekât, belâm Mâcalâni xošawist, to hałeit, Dersîm Tâhir dro nâkât (Ali, 2014: 22).

31) hendék câr hest be lâwâzî dekem, bałâm hendék câr hest dekem zor behézm (Ali, 2014:125).

32) ger či be ruxsâr w rengi pêstidâ genc djâr bû, bełâm seri tewâw spî bû bû (Ali, 2014:117).

Or the contrast between the two segments is implied as Fraser (2009) terms it. Schiffrin (1987: 156) filters the meaning of implied contrast in her own way stating that "the semantic content does not always explain why two units stand in a contrastive relationship" and that "many contrasts are inferable only because a particular proposition violates speaker/hearer expectation-expectation which are grounded not in prior propositions in the discourse, but...in background knowledge about the world". Similarly, Blakemore (2002:104) argues that "the assumption which the speaker cancels through his use of but is not always one which may be derived inferentially from the preceding segment. It is simply an assumption derived from the hearer's encyclopedic knowledge,"

Halliday and Hasan (1976) and Schifirin (1987: 170) suggest that in its contrast sense, 'bełâm' (but) means 'legeł ewešdâ' (however or despite that) and leget ewešdâ alternates bełâm, but not vice-versa.

33) Mâcidi gûł solâv min čûmete cengewe w mirovm kûštwe, bełâm bûke šǔšešem firoštwe...( Ali, 2014: 232).

The above sentence can be re-written in this way; 
34) Mâcidi gûł solâv min čûmete cengewe w mirovm kûštwe, legeł ewešdâ bûke šùšešem firoštwe.

As the following extracts from the novel are considered as implied contrast

35) min w Megholi herdukmân gemža bûin. bełâm demân zâni čon kâspi be 3aqli xomânewe bkein (Ali, 2014: 47).

36) min be drežâî ew šawe wistim seirî nekem, bełâm pâš mâwejek hâta ser mezekemân (Ali, 2014: 124).

37) ême dezânîn pjâw kuż lem šâredâ hezâri ea filséke, bełâm ezânin ewe xałki xâwen birwân , dest w xeti ewa šteki tre, mitmâne w nâwi éwe bo éme šweneki zor degret. (Ali, 2014: 128).

In the last extract (37), the disparity is between two mindsets, which is one of the uses of 'but' pointed out by Schifirin (1987: 153). Moreover, 'bełâm' is used for self-repair in certain settings, as in:

38) . wek ewe bû šikistî žinân lew tajafa ma3ûnadâ râ bigajanin, bałâm nâ... (Ali, 2014: 376).

In its contrast meaning, bełâm can also be substituted or alternated by her čonék bét (any way), which is pointed out by Schifirin (1987: 170), as in;

39) Šibir râsti dekird ,kes be âsâni nedageište Newmirân, belâm dozînewei Ca3fari maghol bû be xûljâm. (Ali, 2014: 254).

Which can be expressed by using har čonek bet (any way) as an alternate, as follows;

40) šibir râsti dakird ,kas ba âsâni nadagaišta newmirân, har čonek bet dozînawai ca3fari maghol bû ba xûljâm. (Ali, 2014: 254).

Thus, it can be detected that belâm is transposable with two other contrastive elements, legal eweš and herčonek bét, (as in English). The frequency of using belâm is (407) which is (\%38) and walé in contrastive sense is only twice, (, i.e.,), (\% 0.2), that can be considered a conservable frequency. However, in the novel, there are instances of 'bełâm', which neither conveys contrast nor Adversative proper, but they can be deemed as Topic shift markers.

41) Mûrtezâ wek leser šânojak westâ bet, destî berz krdewe w wtî, Megholi hâwerei...ei pjâwa gewre mîr zâdakân..ewe nâbet ewe le bîr bken.bełâm îš, îlâhî , legel îšdâ deleit čî... (Ali, 2014: 588).

42) tâke štek be zârmdâ hât ewe bû błêm "lé gerén âsûde bixawét", bełâm rástjakai xošm nem dezânî eabestm čje? (Ali, 2014: 31).

43) zor câr nexša tâzekânmân leser naxša konakânmân dakešínawa, îdî ba corek hełakân ba jakdâ dačin âsân la jakdî cjâ nâkrenawa. Âh...bałâm îtir be dang ba ai âzâri zor błe w bad go... (Ali, 2014: 18).

In the novel, (59) samples of the use of batâm for topic shift has been used, that can be found in pages $(13,34$, $42,135,62,73,88,55,100,102,135,154,155,147,168,176,320,365,376,509,625,726$, etc...). Furthermore, there are certain cases that cannot be dealt with either of the previous cases, hence; it can be treated as vague or especial cases of bełâm (but).

44) debé te bigait am kiča xajâhî nja, dabet te bigain, min čand roża damawet te bigam ka handek zindawar haja zor bičûkin, zor zor bičûkin ba čâw nâbinren, handek zindawari dîkaš han zor gawran,ba hastawara âsâi w be twânâkâni ema nâdozrenawa. Damawe te bigam rwak haja datwânin mirov bixon, bałe datwânin mirov bixon. Bałâm kešai am kičai to awaja ke xajâlî nja. (Ali, 2014: 54).

In the above extract, belâm is not used for contrast, in such a context, as if the novelist brings out various examples, which seems to be unrelated to the main idea 'xajâłi nja', which is also mentioned at the last part of the segment.

45) dabét emro tâ ewâre mâmostâjaki xejâł bidozmawa, Husni be kemék te râmânewe gûtî “ bełâm č core xejâłek ? šéwai zore (Ali, 2014: 75).

46) bełâm Hesení pîro bew šewaje. Hesen, bełâm pâki xošjân ecgâr xoši dewé (Ali, 2014).

These different uses and senses of betâm (but) expose the statement as why they are known as problematic. Though, it has meaning which is mainly of contrast, but the meaning is not a semantic one, but rather a pragmatic one; since the context identifies different interpretation of belâm, whether it is Adversative proper, contrast, topic shift, speakers' return function or else. In terms of position, betâm mostly appears medially,

\section{S1, DM S2}

\section{S1.DM S2}

There is only one sample from the data that the author initiates a section with 'bełam', however, it is connected 
to a discourse segment which is not ended formerly in the previous. The section starts with;

47) bełâm, ei melâ Gherîbi Hâcer či be ser hât? (Ali, 2014: 86).

The researchers also consider this use of betâm for topic shift, because the last words of the section states that "kameki tir tewâwi čîrokakatân bo degermawa...kemeki tir. (Ali, 2014: 86).

\section{Welê (but)}

It can be detected that the novelist utilizes welê on behalf of belâm in certain locus. Welê is a Persian word and conveys contrast meaning, the following are the tokens from the novel;

48) ezmûni sâłâni pêšû le hizbdâ fêri kirdbûm zor derbârei kûžráwakán nepirsm, ewe nebû fizulm nabet, wale ezmûn ferî krdim nâstinî nečirakân eš w âzâri zori ba dwâwaja (Ali, 2014: 51).

49) ew lew core kesâna bû ke herdem čâwerwâni qâsi w pajâmheeneki xajâłin, bet w žjân bigoret, wele lê aw terz w šewa xałkadâ xazallnûs le rîzi rastgokândâ bû. (Ali, 2014: 88).

As it is uncovered, wele is analogous to betâm in terms of meaning and even position. It appears twice in the novel, which is (\%0. 2) of the whole of Adversative DMs.

\section{S1, DM S2}

\section{Betkû (but)}

Contrastive meaning is also verbalized by another reciprocal lexical expressions to belâm, such as betkî.. This lexical item is of frequent use in the novel in different positions in contrastive meaning, which arrives (27) times, with the percentage $(\% 3)$.

The following are some extracts from the novel;

50) hič jekêk le ême ke be rêgâdâ deroin nexšeeak le girfânmândâ nje, betkû komelłek nexšei tekełâw pekdâčû le sermândâje. (Ali, 2014: 17).

51) Trîfa jâ behri w ewâni itr wâ dezânin min derjâwâneki tirsnokim , batâm min tirsnok nîm, bałkû pem wâje nâšet bew core xejâł tekełáwi żjân bikeit. (Ali, 2014: 22).

52) nâ leber aw eawâw hewese kilâsikjai la belâget w dârištinî nûsînekedà heje,bełkû leber ewej xwendnewei bašî em kiteba tüši be bâwerî w gûmânmân deken (Ali, 2014: 38).

53) pedšâ le râstîdâ pedšâi garîm w dûžmnî nekûštwa, belkû pádšâkai nâw rohi xoi kuštwe (Ali, 2014: 759).

Accordingly, betk $\hat{u}$ can be alternated by belâm with the same effective contrastive meaning in the above instances.

Thus, it can be grasped that there are more than one allomorph for betâm in Kurdish that bears a 'contrastive meaning. This diverse meaning may result in semantic ambiguity, similar to but in English, which is claimed to be ambiguous by Abraham (1979), yet this claim is confronted by (Hussein, ND: 2) who sustains that "but is not ambiguous, but it is sense-general linguistic expression" he (Ibid:2) backs up his argument by toting up data from standard Arabic as there are four different non-synonymous linguistic expressions in Arabic "lakinna, bainama, bal and lakin' representing the four different meanings of 'denial of expectation', 'contrast', 'correction' and 'cancellation' respectively.

As a matter of fact, (Husseni, ND) gets insight from the relevance theory of Blakemore (1987), who detects four meanings of but, as Salih (2014) also does. Though, in this study, the instances of 'but' convey the four dissimilar meanings; however, there are instances that can not be dealt with by Relevance Theory. Additionally, Blakemore (2002), herself, in her latest study of 'but', states that her "definition of the procedure encoded by but requires modification", furthermore her approach is a cognitive one. Blakemore $(2002 ; 108)$ relates but to a specific cognitive effect that "but encodes the information that the relevance of the segment it introduces lies in the cognitive effect of contraction and elimination".

Therefore, the researchers get insights from the pragmatic view of Halliday and Hassan (1987), Fraser (2009) and Schifirin (1987), who deal with but in more detail and what is more distinguishable of these works is that, the data are mostly from real conversation and from daily discourse rather than noncontextualized sentences. Since contrastive meaning is not so straightforward and mostly inferred from the context, it is not easy to pick a theory from English and apply it to the lexical items in Kurdish. Blakemore (2002) asserts the fact that, "Contrasts are not always determined by the linguistically encoded meanings of the words used", but rather it "must be derived inferentially on the basis of contextual assumptions", (Blakemore, 2002: 99). Therefore, distinct meanings of betâm are identified which are: 
a) but containing and.

b) Contrastive; direct and implied, self-correction, topic-shift.

c) Other cases that seem to be vague.

Additionally, there are two synonymous lexical items used in the novel with the same sense and pragmatic effect contrast, which are wale and betk $\hat{u}$. These DMs also have the same position of bełâm, which is the middle position between the two discourse segments; S1 and S2.

\subsubsection{Contrastive}

\section{Avowal; le rastîdâ (in fact), râsjekei (to tell the truth), be râst}

Adversative relation in Kurdish can be spoken by a number of items such as le râstîdâ, râstjakei, râstît pe blêm which are counterparts to English in fact, as a matter of, to tell (you) the fact. These expressions are within the internal use of Adversative relative meanings within Halliday and Hasan (1976: 253)'s framework. They imply that "as against what the current state of the communication process would lead us to expect, the fact of the matter is...", rather than 'in spite of the facts', (Halliday \& Hasan, 1976: 254). Biber and Finegan (1988) label in fact and actually as stance adverbs. For them (1988: 1) stance adverbial are adverbials that show "some aspect of speakers' (or writers') attitudes towards their messages, as a frame of reference for the messages, an attitude toward or judgment of their contents, or an indication of the degree of commitment towards their truthfulness", (ibid: 1988: 2).

The discourse functions of such adverbials are "often at variance with their literal meaning" (ibid, 1988: 17), such as solidarity, shared familiarity, emphasis, rather than actuality (as indicates in British spoken and written corpora, ibid, 1988: 30).

However, the study done by Oh (2000) demonstrations that actually and in fact has dual functions, one of them is "contradicting prior expectations", (Oh, 2000: 252). The following excerpts has been chosen from the novel,

54) ew hendêk câr râ guzer pei gutbûm ked dłî mnî lâ mabasta, bałâm zû zû ew qsânai bîr dačwawa w le jekem derfatdâ pjâmdâ heł šâxâ. Le râstidâ pitr le čwâr sâł bû ke le Trîfa jâ behrî zjâir kčeki díkam nedenâsi. (Ali, 2014: 207).

55) xwdâje âfrat lew štânadâ čende le emai pjâw zirek tirn, râstitân dewét éme lew core kârânedâ berember be xânmân hîč nîn (Ali, 2014: 204).

56) her kes le dâik debé beši xoi xajâłi xoi heje, le râstîdâ min be nâčârî wâ dełem (Ali, 2014: 275).

57) min čâwere dekem lem rożânadâ bimkûžin, râstjakai herdukmân čâwerei ewe dekein bimân kužin (Ali, 2014: 560).

58) hewłim dâ be zmâneki sâde lejân biprsim, ke be nâwbangtrîn bâzrgâni mriška, bełkû lew regâjewe dergâm bo bikenewe w bigem ber qâpî nhenjak. Le râstîda kes neidezâni ke benâwbângtrîn bâzrgâne (Ali, 2014: 255).

In the above extracts, the italicized convey a contrastive meaning and denote that " as against what the current state of the communication process would lead us to expect, the fact of the matter is...". Hence, they are DMs of adversative type. They are utilized (33) times, (6.2\%) within the following loci;

\section{S1, DM S2}

\section{S1. DM S2}

Accordingly, they occupy the middle position, after comma or full stop and the meaning they indicate is that, prepares the reader for an idea opposite the preceding one.

\subsubsection{Correction Relation}

\section{Correction}

The general meaning of this sort of adversative relation is 'contrary to expectation' but the specific meaning is 'as against what just has been said', and "one formulation is rejected in favor of what you have been told' or 'in favor of another". (Halliday \& Hassan, 1987: 254), The selected lexical elements in this group in the novel are as follows:

\section{a. Correction of Meaning}

\section{Kečî (instead)}

Keč $i$ is the item that conveys 'correction of meaning' within the Adversative meaning. In The Sharazoor's (2000) dictionary, it is listed as a conjunction. Keči is studied within the grammatical scaffold in Kurdish language. 
Ibrahim (1986: 250) considers it as one of the syntactic particles that relates the subordinate clause with the main clause. And in terms of position, he (ibid) reports that it occupies the middle position, whereas Mahwi (2011: 229) terms 'kečì' as a conjunctional adverb that ties up sentences rather than words or phrases, whereas Fattah (1997: 250) considers it as a member within concessive/ conservative coordinators, like 'bełâm' and ' egînâ'. In order to recognize the status of kečl as a DM the following instances are designated;

59) câr bwe leser šti bičûk tûre bwe. Keč̂̀ gutî "cwân dabet, bo cwân nâbet, xerîke xwendnekei bo derdečet derwât bo Ingilterâ jân Almân. (Ali, 2014: 124).

60) ger čî qsekâni bâwki zor be ešw âzâr w brîndâr ker bû, keči kičeka dił tengî w brindâri pew djâr eabû. (Ali, 2014: 200).

61) hîč kes peštir be âgâdâri w rezâmendi ew čâwi bew nexšeje nekewtbû, kečî bo jekem câr le žjânîdâ dâweteki Xezel nûsî krd (Ali, 2014: 460).

Fraser (ND) pins a number of uses of 'instead' that can be applied to the above examples from the novel and the result is that they can be considered as DMs;

S1 specifies a state or action that was not done while S2 specifies a state or action that was done as an alternative. (There are other constraints such as the subjects of S1 and S2 be the same unless there is a negative pronoun as the subject of $\mathrm{S} 1$ ).

He (ibid: 1) identifies a number of limitations for each use as,

(A) The main verb of S1 to be explicitly negated or should have negative pronoun, such as (nobody, nothing)

(B) Negative adverbs such as (few, hardly ever, rarely, seldom, never...)

(C) Negative message may be implied in S1.

(D) And $\mathrm{S} 1$ includes 'positive conditional modal verbs.

A second use occurs when S1 specifies a state or action that did occur and S2 specifies another action, which serves as an alternate for the S1 action. (Fraser, ND: 1-2). It can be observed that the same conditions are met within the extracts from the Kurdish novel regarding the use of 'kečì' (instead). kečl is almost seen in the middle, and the procedures take the following forms:

S1, DM S2

S1. DM S2

The frequency of this DM in the novel is (6) times, in percentage (1.13\%).

\section{b. Correction of Wording}

\section{Belkû (rather)}

When the meaning of Adversative/contrastive is explained in the previous sub-section, this lexical item appeared as an alternative for 'but'; however, in the following examples 'bełkû' conveys another meaning, which is translated as 'rather', as follows:

62) nâbet wâ bizânin ke Trîfe jâ behrî be pilân šti wehâi kirdwe, belkû xejâł cüratî bexšje ew kičâne qise biken, xejâlliš kîsełeki xâwe, zori dewet tâ ferî debîn (Ali, 2014: 174).

63) estâ griftî gewrei min ewe nje čon dâr w dîwâr berz bikememewe, belkû čon šârek dirûst bikem pir xejâł bet. (Ali, 2014: 567).

64) nâ leber ew hewse klâsikjai le belâget $\mathrm{w}$ dâršynî nûsînekedâ heje, betkû leber ewej xwendnewai hendé bešî em ktébe tûŝî dû dłî w be bâweri w gûmânmân dekât (Ali, 2014: 38).

In the above examples, if betk̂े were substituted by betâm, the resultative meaning would not be the same. Consequently, in such contexts the meaning of bełk $\hat{u}$ is not betâm for contrast, but rather expresses 'correction' meaning.

On the syntactic level, Ibrahim (1986: 43) tackles betk $\hat{u}$ stating that, it is "one of the commonly used elements in Kurdish, used to join two simple sentences". Betk $\hat{u}$ is explained by grammarians, like McCarus (1958). He sets down betk $\hat{u}$ as a conjunction and glosses it as 'perhaps'. This is an indication that betk $\hat{u}$ can also be used for possibility; however, he (ibid, 1958: 100) does not comment on any 'contrastive' or 'correction' use of this element. In the novel, betk $\hat{u}$ is utilized in this sense as the following example reveals;

65) be râi min tâ kâteki tir dâi pošinewa, betkû bîreki wrd trî lé bkainawa (Ali, 2014: 32). 
Shwani (2000:113) also confirms on the use of betku as a conjunction relating 'suspect' subordinate clause.

66) bełkû hezârân kesiš hebûn le câde râwestâbûn.

67) Xot bigre betkû degeme cé (Shwani, 2000: 49).

It is worth mentioning that betk $\hat{u}$ is usually used in the middle position, though in examples above, Shwani (ibid) uses it initially, but here, the first part of the conversation is ignored, since the study is not grammatical, and does not mean to have pragmatic interpretation.

Fraser (2006) in his study on rather and instead, reports on the uses of 'rather' as a DM and the conditions for its utilization, as mentioned in the previous section in 'keči'. Applying the same conditions to the data from the novel, it is found out that betk $\hat{u}$ is a DM. In all the three other instances, S1 is negative. Similarly in:

68) wesfî xânuekân xojân nâkât, betkû bâseki xajâlłi le żjâni awâne dekât ke le newîdâ dežîn (Ali, 2014: 80).

69) hendék le xâwljakâniš bo ifroštin nebûn, bo dest le dân nebûn, betkû bo ewe bûn sirjân bikeit w gwé le hikâjete dwrû drežekânjân bigrît ke Hūsnî be lezetekî be endâze deigerâjewe (Ali, 2014: 80).

It can be predicted from the data that,

a) when $\mathrm{S} 1$ is positive 'but' has a contrastive meaning(, i.e.,) means bałâm, but,

b) when $\mathrm{S} 1$ is negative whether explicitly or implicitly, bełkû reveals correction sense.

Betk $\hat{u}$ is used in correction sense (49) times, that is (9.3\%), and it occupies middle position.

\section{S1, DM S2.}

\section{Be pečewânewe (on the contrary)}

The prepositional phrase be pečewânewe, which is translated as 'on the contrary' bears 'correction' meaning. In English ' on the contrary' signals that the speaker of S2 considers S1 to be an incorrect representation of the same action, state or property attributed to an aspect of that segment, and offers S2 as the correct representation", Fraser (2009: 88). be pečewânewa appears in the novels so frequently in two different forms, different positions and functions, the segments of S1 and S2 are contrastable. The following are a handful of the its occurrences;

70) pét sejr nabetke błem ewei minî gejânde ew birwâje , ewe bû ke min w to le jek dečîn, be pečewânewe, min w to sed der sed cjâwâzîn (Ali, 2014: 558).

And also occurs as 'be pečewâwnei' as in;

71) dwâi gerâneki dûkândâreki câmâne beser, be xoj w smełekejawa, be pečewânai frošjâre deng wišk w be dengekâni em šâre (Ali, 2014: 256).

72) leber hojeki nezânrâw čîroki em mämostâjai xejâtî le hâwrekâni xoi šâredewe. Be pečewânei Šemsewe ke be šânâzjewe bâsi bâš bûn w zîrekî kičakai dekird (Ali, 2014: 292).

As indicated, the first instance can be considered as a DM, while there are (11) other cases are not DMs; hence, the percentage of utilizing this marker is $(0.1 \%)$. This DM occurs in the middle and the procedure is:

\section{S1, DM S2}

\subsubsection{Dismissive}

Dismissive simply denotes 'let's leave that aside and turn to something else', Halliday and Hasan (1976: 255). There are a number of listed DMs that express dismissal in English, such as however, anyhow, in any rate, any way, etc. In the Kurdish novel, there are a number lexical expressions convey this meaning, except for 'her čende' (any way), which functions as a DM.

\section{Be her hâl (any way)}

Be her hât is the adverb in terms of its syntactic function and the English translation is 'anyhow or anyway'. Marif (2004: 24) labels such adverbs that are composed of a group of words without containing any verb in its component as 'syntactic adverb'.

In order to study the statues of this expression as a DM, the following occurrences which are (5) instances; as be her hât would be investigated to decide their being as a DM.

1) Hûsni wek hemû kâsbe dił frâwânekânî bâzâr serî bâdâ w gutî be her hât em segâne her rože w štek dedoznewe bo ewei pâre bikešewe, her rožai hîkâjetek dâdehenin" (Ali, 2014: 74).

2) Sâlânekî dûrw drež le bendîxâne debet, be her hât heštâ xoš bextît, estâ bendîxânekân wek cârân nemâwn, pâktr w bâštrin, bałâm âsân nja (Ali, 2014: 755). 
Be her hât occupies middle position within the discourse segments, whether after a comma or after a full stop, but it does not occur initially or finally, as a DM.

S1, DM S2

S1.DM S2

Coll (2009: 141) in her study on 'any way, describes this DM as a 'marker of digression'. Digression is a "deviation from the main point, central theme or topic, or purpose of discourse" that can be conscious or unconscious. The same notion of 'digression' is applicable to the segments in the Kurdish novel, as the discourse topic deviates from one topic into another. It can also be observed that be her hât connects more than one discourse segments. This is the case for English 'any way' as Ferrara (1997: 355) points out that any way “connects more than two'. The percentage of use of this marker is $(0.94 \%)$ as revealed in the table bellow:

Table 1. Adversative DMS in the Novel

\begin{tabular}{|c|c|c|c|c|c|}
\hline \multirow{15}{*}{ 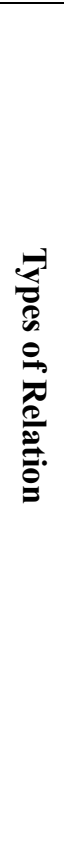 } & Sub-types & DMs & English translation & Frequency & Percentage \\
\hline & \multirow{3}{*}{ Simple } & Héštâ & yet & 1 & $0.1 \%$ \\
\hline & & (E)ger čî & (al) though & 1 & $0.1 \%$ \\
\hline & & Tenhâ & Only & 0 & $00 \%$ \\
\hline & \multirow{7}{*}{ contrastive } & Bełâm & & 407 & $38 \%$ \\
\hline & & Welê & but & 2 & $0.2 \%$ \\
\hline & & Bełkû & & 27 & $3 \%$ \\
\hline & & Le râstîdâ & In fact & & \\
\hline & & Râstjekei & To tell the truth & 33 & 6.30 \\
\hline & & Be râstî & Actually & 33 & $0.3 \%$ \\
\hline & & Ke čî & Instead & 6 & $1.13 \%$ \\
\hline & \multirow[t]{2}{*}{ Correction } & Bełkû & Rather & 49 & $9.3 \%$ \\
\hline & & Be pèčewânewe & On the contrary & 1 & $0.1 \%$ \\
\hline & \multirow[t]{2}{*}{ Dismissive } & Be her hâł & Anyhow & 5 & $0.94 \%$ \\
\hline & & Total & & 531 & $100 \%$ \\
\hline
\end{tabular}

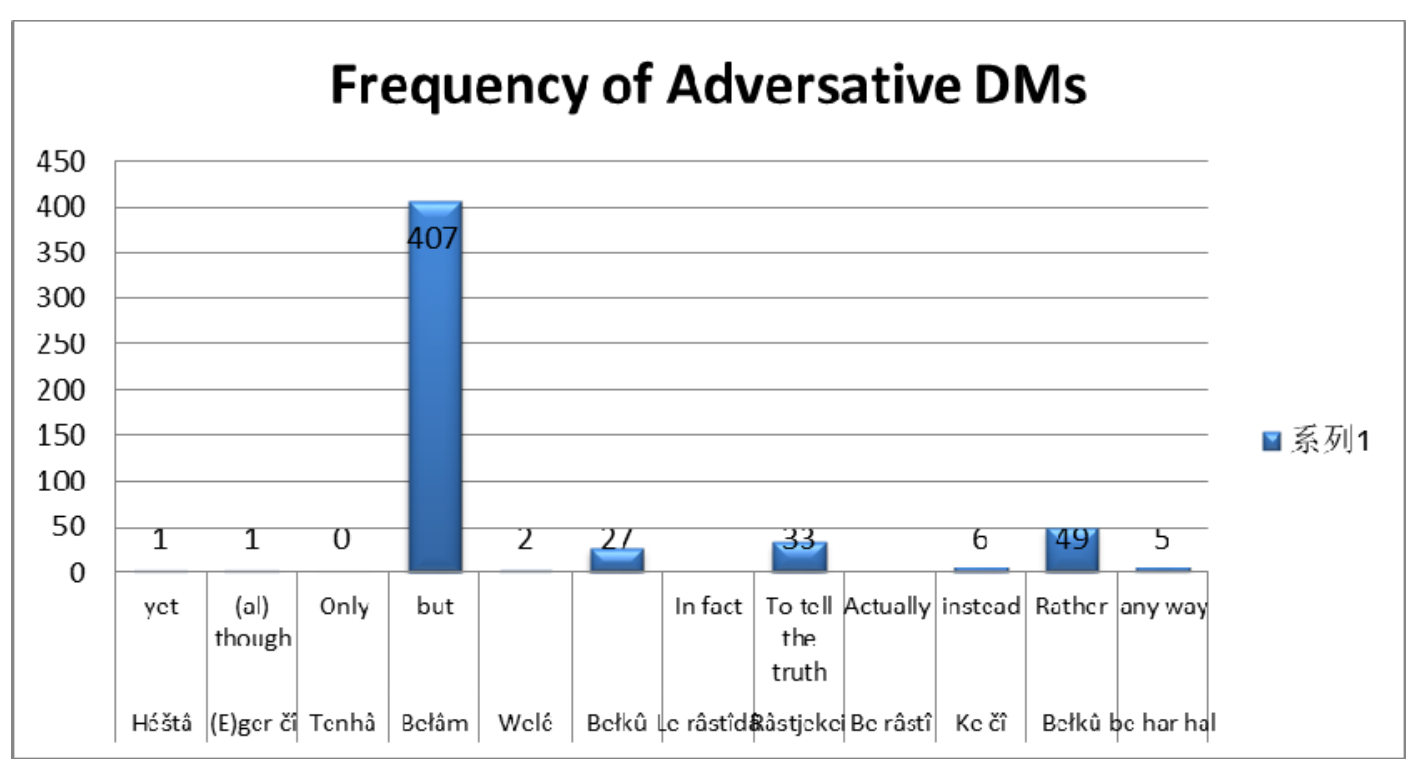

Figure 2. Frequency of adversative DMs in the Novel 


\section{Conclusions}

From the previous investigation of Adversative DMs in Kurdish literary text, it can be concluded that, Kurdish discourse structure like other living languages, contains DMs and have different forms, meanings and also different discourse functions.. Therefore, it can be stated that in Kurdish DMs are lexical expressions that are part of the discourse segments, and they are derived from different grammatical categories such as conjunctions, adverbs, prepositional phrases etc.

Through qualitative research methods that are by analyzing the DMs manually, and converting them into statistical means the researchers could answer the research questions that DMs are used to a large extent in Kurdish literary texts, which is reflected in various frequency of uses, and they are derived from adverbs, conjunctions, prepositional phrases.

It is also concluded that the model proposed by Halliday and Hassan (1976) is applicable to the DMs in Kurdish. Accordingly, Adversative DMs in Kurdish have the same categories of that of English proposed by the Hallidayan frame, which are; simple, contrastive, correction and dismissive' though, it is not as easy as it can be perceived to categorize these markers under the sub-categories of Halliday and Hassan (1976), since the markers convey different meanings and can be utilized under more than one categorization; for that purpose, other models have been implemented to treat those certain cases which turned out to be untreated by the basic mode, such as Fraser (2009). And in terms of position they either initiate discourse or occur medially to connect discourse segments, but there are not instances of final position DMs in the literary text.

\section{References}

Ali, B. (2014). Xezelnûs w Bâxaekani Xeyat. Endeše for publication: Sulaimani.

Biber, D., \& Finegan, E. (1988). Adverbial Stance Types in English. Discourse Processes, 11, 1-34. https://doi.org/10.1080/01638538809544689

Coll, M. (2009). Anyway' A Formal Approach to the Syntax and Semantics of Discourse Markers. Published Thesis: University of Essex.

Fattah, M. (1997). A Generative Grammar of Kurdish. Unpublished PhD Dissertation.

Fraser, B. (ND). The English Contrastive Discourse Markers instead \& rather.

Fraser, B. (1999). What are Discourse Markres? Journal of Pragmatics, 31, 931-952. https://doi.org/10.101 6/S0378-2166(98)00101-5

Fraser, B. (2009). An Account of Discourse Markers. International Review of Pragmatics, 1, 293-320. https://doi.org/10.1163/187730909X12538045489818

Halliday, M. A. K., \& Hasan, R. (1976). Cohesion in English. London: Longman.

Marif, A. (2004). Berheme Zmanawanjakanim “nusin w wargeran”. Serdem for Publication: Sulaimani.

Mardoyan, L (ND). The Correlation of Adversative and Causal Discourse Markers.

McCarus, E. N. (1958). A Kurdish Grammar: Descriptive Analysis of the Kurdish of Sulaimanya, Iraq. New York: Spoken Language Services Inc.

Oh, S.-Y. (2000). Actually and in fact in American English: A data-based analysis. English Language and Linguistics, 4, 243-68. https://doi.org/10.1017/S1360674300000241

Qazzaz, S. (2000). The Sharazoor Kurdish-English Dictionary. Aras Press and Publishers. Erbil Press/ Kurdistan

Salih, R. R. (2014). A Comparative Study of English and Kurdish Connectives in Newspaper Opening Articles. Published PhD Dissertation.

Shwani, R. M. (2002). Amrazi Bestnewe le Zmani Kurdîda. (Conjunction in Kurdish). Slemani: Serdom Press.

Schiffrin, D. (1987). Discourse markers. Cambridge: Cambridge University Press. https://doi.org/10.1017/CB O9780511611841

Wahby \& Edmonds. (1966). A Kurdish-English Dictionary. Oxford: Oxford University Press.

\section{Note}

Note 1. Since Fattah (1997) adopts a TGG approach in his study of Kurdish Grammar, drawn from Chomskeyan tradition, he (1997) makes use of such terms as 'specifiers', by which he means those dependents preceding the 
Noun head within the external structure of the noun phrase (NP).

\section{Copyrights}

Copyright for this article is retained by the author(s), with first publication rights granted to the journal.

This is an open-access article distributed under the terms and conditions of the Creative Commons Attribution license (http://creativecommons.org/licenses/by/4.0/). 